\title{
Older adult females hospitalized with cardiovascular disease outweigh male older adults in receiving Potentially Inappropriate Medication
}

\author{
rishabh Sharma ${ }^{1}$, Parveen Bansal ${ }^{2}$, Manik Chhabra ${ }^{3}$, and Malika Arora ${ }^{4}$ \\ ${ }^{1}$ Affiliation not available \\ ${ }^{2}$ Baba Farid University of Health Sciences \\ ${ }^{3}$ Indo Soviet Friendship College of Pharmacy \\ ${ }^{4}$ Guru Gobind Singh Medical College and Hospital
}

April 13, 2021

\begin{abstract}
Introduction: There are a lack of potentially inappropriate medications (PIMs) predictors among the geriatric population with cardiovascular disease (CVD). Objective: This study was focussed on finding out the predictors and prevalence of PIMs use in the older adult patients hospitalized with cardiovascular disease. Methods: This prospective cross-sectional study included 250 older adult patients (mean age 69.03 \pm 5.76 years) with the CVD having age 65 years or more, admitted in the cardiology/medicine department of a tertiary care hospital. PIMs were identified as per Beers criteria 2019. Binary Logistic regression analysis was used to determine the predictors of PIMs use in older adult patients. Results: Results indicate a very high PIM prescription rate of more than $62.4 \%(n=156)$ with Proton pump inhibitor, short acting insulin according to sliding scale, Enoxaparin $<30 \mathrm{ml} / \mathrm{min}$ as the most commonly prescribed PIMs. On Binary logistic regression, important predictors for PIMs use were found to be females (odds ratio [OR] 2.36, 95\% confidence interval (CI) 1.36- 4.09, $\mathrm{P}=0.002$ ), three diagnosis (OR 4.29, 95\% CI 1.31- 14.0, $\mathrm{P}=0.016$ ), [?]4 diagnosis (OR 4.8, 95\% CI 1.49- 15.44, $\mathrm{P}=0.009$ ), 7-9 days of hospital stay (OR 4.74, 95\% CI 1.07- 20.96, $\mathrm{P}=0.04$ ), [?] 9 medications per day (OR 0.09, 95\% CI 0.01- 0.50, $\mathrm{P}=0.006$ ). Conclusion: The prevalence of PIMs in older adults with cardiovascular disease is very high, and females with CVD have emerged as a potential PIM indicator. The study also indicates a lack of awareness towards Beer criteria in health care workers (physicians/pharmacists/nursing staff) leading to PIM.
\end{abstract}

Older adult females with cardiovascular disease outweigh male older adults in receiving Potentially Inappropriate Medication

Running title: Inappropriate prescribing in older adult patients

\begin{abstract}
Introduction: There are a lack of potentially inappropriate medications (PIMs) predictors among the geriatric population with cardiovascular disease (CVD).

Objective: This study was focussed on finding out the predictors and prevalence of PIMs use in the older adult patients hospitalized with cardiovascular disease.

Methods: This prospective cross-sectional study included 250 older adult patients (mean age $69.03 \pm 5.76$ years) with the CVD having age 65 years or more, admitted in the cardiology/medicine department of a tertiary care hospital. PIMs were identified as per Beers criteria 2019. Binary Logistic regression analysis was used to determine the predictors of PIMs use in older adult patients.
\end{abstract}


Results: Results indicate a very high PIM prescription rate of more than $62.4 \%$ ( $\mathrm{n}=156$ ) with Proton pump inhibitor, short acting insulin according to sliding scale, Enoxaparin $<30 \mathrm{ml} / \mathrm{min}$ as the most commonly prescribed PIMs. On Binary logistic regression, important predictors for PIMs use were found to be females (odds ratio $[\mathrm{OR}] 2.36,95 \%$ confidence interval $(\mathrm{CI}) 1.36-4.09, \mathrm{P}=0.002$ ), three diagnosis $(\mathrm{OR} 4.29,95 \% \mathrm{CI}$ 1.31- 14.0, $\mathrm{P}=0.016$ ), [?] 4 diagnosis (OR 4.8, 95\% CI 1.49- 15.44, $\mathrm{P}=0.009$ ), 7-9 days of hospital stay (OR 4.74, 95\% CI 1.07- 20.96, $\mathrm{P}=0.04$ ), [?] 9 medications per day (OR 0.09, 95\% CI 0.01- 0.50, $\mathrm{P}=0.006$ ).

Conclusion: The prevalence of PIMs in older adults with cardiovascular disease is very high, and females with CVD have emerged as a potential PIM indicator. The study also indicates a lack of awareness towards Beer criteria in health care workers (physicians/pharmacists/nursing staff) leading to PIM.

Keywords: Beers Criteria, Cardiovascular disease, older adult patient, potentially inappropriate medication

\section{Impact of findings on practice statements}

- Increased prescribing of Potentially Inappropriate Medication among older female patients with cardiovascular disease is a serious health issue that warrants immediate medical attention.

- The high prevalence of medications that should be avoided or their dosage reduced according to the kidney function of the older adult patient shows the need of medication management while prescribing in older adults.

- Polypharmacy and hyperpolypharmacy is associated with the use of PIM in the older adults.

\section{Introduction}

PIM is defined as those medications whose adverse risk outweighs its health benefits, mainly when safer or alternative treatment is available. ${ }^{[1]}$ PIMs use in the older adults is increasing day by day due to several underlying reasons, including lack of knowledge about the application of Beer criteria among the physicians and health care workers. ${ }^{[2]}$ PIMs use is also increasing due to a lack of classified PIM predictors for various diseases. Various studies have reported a high prevalence of PIMs in the USA, China, and the Indian older adults and are estimated to be within the range of $25 \%-90 \%$ as identified by different validated criteria. ${ }^{[3-5]}$ The prevalence of CVDs along with other comorbidities is widespread in the older adults. CVDs such as hypertension, coronary heart disease, congestive heart failure, stroke, etc are the most common cause of death among the older adults. ${ }^{[6]}$ PIM use is very harmful to the geriatric population, specifically to patients suffering from CVD and other comorbidities and can lead to severe outcomes. ${ }^{[7]}$ Older adults is considered frail and more vulnerable to adverse drug events or any medication-related problems due to polypharmacy/high level polypharmacy to treat comorbidities. ${ }^{8]}$ Moreover, age-related changes in the physiology of the older adults might also alter the pharmacokinetics and pharmacodynamics of drugs. ${ }^{[9]}$ Despite this, PIMs continue to be prescribed as a first-line treatment in the older adults, and the increased prevalence of PIMs in the older adults is an issue of grave concern. ${ }^{[10]}$ Identify inappropriate use of medication in the older adults having to age 65 years or more is of supreme importance.

Various tools like Beer criteria have been developed to determine the use of PIMs in the older adults and minimize the drug-related problems associated with PIMs use. Numerous studies have been conducted to find out the prevalence and predictors of PIMs in the older adults. Still, very few studies have been conducted to find out the PIMs use in the older adult patients hospitalized with CVD. Studies have documented the prevalence of PIMs in CVD older adult patients in a different health care setting. In a recent study, $87.4 \%$ of patients received at least one PIM in cardiology service. ${ }^{[11]}$ However, there is a complete lack of data on PIMs predictors in older adult patients hospitalized with CVD. Hence, the present study's main objective was to determine the prevalence and predictors of Potentially Inappropriate Medication in older adult patients hospitalized with cardiovascular disease using Beers criteria 2019.

\section{Materials \& Methods}

A prospective observational cross-sectional study was conducted in a tertiary care teaching hospital of Punjab in north India after obtaining Institutional Ethics Committee (IEC) clearance in accordance with the Indian Council for Medical Research Bioethics guidelines (ERB/UCER/2018/9/3). Patients having age [?] 65 
years with a history of cardiovascular disease admitted to the Cardiology/Medicine department willing to participate included in the study after written informed consent.

Data to find out PIM predictors in relation to age, sex, education qualification, clinical features, number of comorbidities, Laboratory and radiological investigations (Serum creatinine value), and drug-related characteristics (number of medications during hospital stay) were noted. All of the patient treatment charts were reviewed daily, and the PIM were identified according to the American Geriatric Society (AGS) updated Beers criteria 2019 applicable to the general population aged over 65 years regardless of the level of frailty or place of residence. The Creatinine clearance $(\mathrm{CrCl})$ value was calculated based on serum creatinine of the patient-reported at the time of admission with the help of the Cockcroft- Gault equation. ${ }^{[12]}$

Statistical analysis was carried out by using Stata 16 (Stata Corp) and Statistical Package for the Social Science (SPSS) free version 24. ${ }^{[13]}$ Numerical data was expressed as mean and standard deviation or median and interquartile range depended on the data's normality distribution. Frequency and percentage were used to express categorical data. The prevalence of PIMs was calculated based on the patient-level as follows.

Prevalence of PIMs= total number of patients with at least one PIMs use/ the total population of the older adult patients hospitalized with cardiovascular disease.

The risk factors related to PIM prescription, including socio-demographic variables like age, gender, number of medications, length of hospital stay, and creatinine clearance of the older adult patients, were assessed using binary logistic regression. The Odds Ratio (OR) with a confidence interval of $95 \%$ (CI) was used for the identification of predictors for prescribing PIMs. P-value $<0.05$ was considered statistically significant.

\section{Results}

A total of 250 older adult patients were admitted to the cardiology/medicine department with the cardiac complaints and met inclusion criteria during the study period. Out of 250 inpatients, $60 \%(\mathrm{n}=150)$ of the patients were males, the median age of the patient at the time of hospital admission was 65 years (range 65- 86 years). About $64 \%(\mathrm{n}=160)$ of the patients belonged to the age group of $65-70$ years, followed by $17.6 \%(\mathrm{n}=44)$ patients aged between $71-75$ years, whereas only $8.8 \%(\mathrm{n}=22)$ of the inpatients were above 80 years. A very high proportion of the patients $(67.2 \%, \mathrm{n}=168)$ were found to be illiterate. Approximately $16 \%(n=40)$ of the patients were a chronic smoker, and the same proportion of patients were found to be a chronic alcoholic, respectively. Table 1 represents the socio-demographic and clinical characteristics of the older adult patients.

It was observed that on average, each patient had 3 diagnosis, and the number of diagnosis ranged from one to seven. However, $36.8 \%(\mathrm{n}=92)$ of the patients were having [?]4 diagnosis during their hospital stay. Moreover, patients have been categorized according to their length of hospital stay as prolonged hospital stay may increase the risk of adverse drug reaction. The median length of hospital stay was 6 days (range 320 days). Also, it was found that nearly one-sixth of the older adult patients $(64 \%, \mathrm{n}=160)$ were prescribed with nine or more than nine medications during their hospital stay. Most of the patients were either on polypharmacy (5- 9 medications per day) or high- level polypharmacy (>10 medications per day) during their hospital stay. On the other hand, several comorbidities were documented in patients. The majority of the older adult patients suffered from chronic diseases such as Ischemic vascular disease (208 patients), Dilated cardiomyopathy (46 patients), followed by 56 patients with congestive heart failure. Figure 1 describes the prevalence of the chronic disease in 250 older adult patients.

A significant decline in kidney functions is often observed in the majority of the older adult patients. In our study, the mean creatinine clearance was $45.62 \mathrm{ml} / \mathrm{min}$ (range $5-156$ ). It has been clarified in Beers criteria that certain given medications either should be avoided or their dosage should be adjusted after having an eye on the kidney function or creatinine clearance of the patient. The mean serum creatinine of the patient was $5.6 \mathrm{mg} / \mathrm{dl}$ (range 2.4- 18). Creatinine clearance $(\mathrm{CrCl})$ was calculated with the help of Cockcroft- Gault formula, and the mean $\mathrm{CrCl}$ was $12.75 \mathrm{ml} / \mathrm{min}$ (range 4- 36). About $37.6 \%(\mathrm{n}=94)$ of the patients were having $\mathrm{CrCl}$ less than $30 \mathrm{ml} / \mathrm{min}$ followed by $33.6 \%(\mathrm{n}=84)$ within the range between $31-60 \mathrm{ml} / \mathrm{min}$. A 
deficient proportion of patients $(4.8 \%, \mathrm{n}=12)$ were having $\mathrm{CrCl}$ above $90 \mathrm{ml} / \mathrm{min}$.

\section{Prevalence of PIMs}

A ccording to AGS updated Beers criteria2019, a total of $62.4 \%(n=156)$ patients were prescribed with at least one PIM as identified by Beers criteria 2019. The details of the overall prevalence of PIMs use in older adult patients hospitalized with cardiovascular disease, as specified in the present study, are shown in Table 2. The most common identified PIMs in the study cohort were Proton pump inhibitor, Short-acting insulin according to the sliding scale, Enoxaparin, to name a few. Overall, $8.8 \%(n=22)$ of the patients were prescribed with at least [?] 3 PIMs, as described in table 1.

On Bivariate logistic regression, Gender female (OR 2.36, 95\% CI 1.36- 4.09; $\mathrm{P}=0.002$ ), three diagnosis (OR 4.29, 95\% CI 1.31- 14.0; $\mathrm{P}=0.016$ ), [?]4 diagnosis (OR 4.8, 95\% CI 1.49- 15.44; $\mathrm{P}=0.009$ ), 7-9 days of hospital stay (OR 4.74, 95\% CI 1.07- 20.96; $\mathrm{P}=0.04$ ), 5-8 medications (OR 0.08, 95\% CI 0.01- 0.40; $\mathrm{P}=$ 0.002), [?] 9 medications (OR 0.09, 95\% CI 0.01- 0.50; $\mathrm{P}=0.006), \mathrm{CrCl} 31-60 \mathrm{ml} / \mathrm{min}$ (OR 0.38, 95\% CI 0.19- 0.75; $\mathrm{P}=0.006$ ), $\mathrm{CrCl} 61-90 \mathrm{ml} / \mathrm{min}(\mathrm{OR} 0.15,95 \% \mathrm{CI} 0.07-0.32 ; \mathrm{P}=<0.001$ ) were found to be important predictors for the potentially inappropriate prescribing in older adult patients. The predictors analysed for PIMs prescribing are summarised in Table 3.

\section{Discussion}

To our knowledge, this is the first study to determine the PIMs use in Indian older adult patients admitted with cardiovascular disease in the medicine/ cardiology department of a tertiary care teaching hospital. This study identified a high frequency of PIMs use in older adult patients according to Beers criteria 2019. It was observed that out of 250 older adult patients, 156 patients had been prescribed with at least one PIM during their entire hospital stay. Inappropriate use of medication is more often occur in older adults as they take multiple drugs simultaneously to treat multiple conditions. A few studies have been conducted worldwide to find out the prevalence of PIMs in CVD, and some studies have reported lower prevalence as compared to our study. On the other hand, few have reported higher prevalence. This difference could be due to a study participant included in different studies, variations in prescribing habits in different countries with different healthcare settings. Another important factor causing variation in the prevalence of PIMs is different criteria used in a different study. In concordance with other studies conducted in different countries, this study's prevalence was lower than that reported by Aguiar et al identified $87.4 \%$ of the patients were taking [?]1 PIM. ${ }^{[6]}$ On the other hand, a study conducted in Spain by Garcia- Ramos et al. reported a $27.9 \%$ prevalence of PIMs in cardiovascular care. ${ }^{[14]}$

The most frequently used PIMs in our study were Proton pump inhibitors from independent of diagnosis category as identified by Beers criteria. Proton pump inhibitor (PPI) is the most commonly prescribed drugs and is chronically consumed without an indicated diagnosis. It is necessary that all health care providers monitor the use of PPI in older adults if prescribed for long term as these drugs may increase the risk of clostridium difficile infection, bone and hip fracture. ${ }^{[15]}$ The second most prescribed PIMs were Insulin Sliding Scale (insulin regimens containing only short or rapid-acting insulin dosed according to current blood glucose levels without concurrent use of basal or long-acting insulin) is an agent approved for diabetic patient. However, in the older adult patients, the older adult patients may have a higher risk of hypoglycaemia without improving hyperglycaemia management. ${ }^{[16,17]}$

According to Beers criteria, Drugs such as diuretics that may cause or exacerbate Syndrome of Inappropriate Antidiuretic hormone secretion and hyponatremia should be used with caution in older adults, especially cardiovascular patients, diuretics are often prescribed to get rid of fluid retention. ${ }^{[18,19]}$ Health care providers are advised to keep a close look at sodium level whenever older adults are prescribed with these medications. However, Beers criteria suggest that Aspirin should be used with caution in older adults with age [?]70.

Nitrofurantoin is first-line therapy for Urinary tract infection. Still, it is considered as potentially inappropriate medication in older adults as these drugs have the potential to cause pulmonary toxicity, hepatotoxicity, and peripheral neuropathy with long term use. ${ }^{[20]}$ 
Long-acting Benzodiazepine was amongst the most commonly prescribed PIMs. As the older adult is mostly suffering from anxiety, depression, and other psychiatric disorders. So, Benzodiazepines are often prescribed to treat these complications in older adults. But Beers criteria recommends that all benzodiazepines should be avoided in older adults as they increase the risk of cognitive impairment, falls, fractures. Moreover, it may worsen the delirium. ${ }^{[21]}$

However, age-related significant changes were observed in the kidney function of older adults. Certain medications should be either avoided or their dosage reduced according to the creatinine clearance of the patient. Despite a clear-cut indication, in our study, we have identified 7 PIMs that have been prescribed to 63 older adult patients with CVD. Among them, especially anti-coagulant, was the most commonly prescribed PIMs. Their dosage either should be reduced or avoided according to Creatinine clearance of the patient as they may pose a threat to older adult patients. ${ }^{[22]}$

The present study also highlights the predictors of PIMs prescribing in older adult patients with CVD. It was observed that the most important predictors of PIMs prescribing were female gender, three or [?]4 number of diagnosis, 7- 9 days of hospital stay, 5- 8 medications and [?] 9 medications prescribed during their hospital stay, and $\mathrm{CrCl}$ of $31-60 \mathrm{ml} / \mathrm{min}$ and $61-90 \mathrm{ml} / \mathrm{min}$. These findings results are consistent with the results from previous findings that have reported the same predictors for PIMs prescribing. ${ }^{[11,23]}$

Although the female gender is increasingly perceived as a key predictor of PIMs, systemic gender studies in the older adults patients hospitalized with CVD are still lacking. Compared to male diabetics, the probability of lethal Coronary Heart Disease (CHD) has been reported to be $50 \%$ higher in women with diabetes. ${ }^{[24]}$ the reason for this higher PIMs used in the female older adults with CVD is multifarious and related to India's social structure. Major factors include sluggishness to move to specialists, social bindings/miserliness, nonadherence to treatment plants due to commitment toward family, increase self-medication for ailments, and easy availability of over the counter drugs. ${ }^{[25]}$

It was observed that the older adults with 3 or [?]4 numbers of diagnosis/comorbidities are more vulnerable to PIMs use than the population with fewer diagnosis/comorbidities. Several studies have reported a decline in quality of care when patients have multiple morbidities. ${ }^{[26,27]}$ several factors contribute to the increased use of PIMs in the older adults with comorbidities. Multimorbid patients tends to have frequent and intensive contact with different specialists' physicians resulting in increased medication prescribing for various conditions. ${ }^{[28]}$ On the other hand, there is a high possibility of a lack of coordination amongst specialists for different disease prescribing under one roof, leading to the prescription of multiple drugs, which increases the likelihood of PIMs prescription.

Prolonged hospital stays (7-9 days) are one of the main predictors of PIMs use as prolonged hospitalization increases the risk of hospital-acquired infection, increased mortality, economic burden, and poor outcomes in the older adults. ${ }^{[29]}$ As the hospital stay of the older adults increases, the consultants intend to get the patient out of the disease irrespective of the drug's side effects and adverse effects. Moreover, there is a complete lack of awareness among physicians about the PIMs and Beers criteria.

Patients with deterioration in kidney function are more susceptible to nephrotoxic injury due to the inappropriate dosing of medication. ${ }^{[30]}$ Moreover, due to the unwanted effects of drugs mentioned in Beers criteria, there is a strong chance of prescribing an inappropriate drug dose that may cause nephrotoxicity in the older adults with altered kidney function.

Nowadays, the older adult is often on polypharmacy/high-level polypharmacy to treat their condition. Furthermore, increased use of drugs in older adult further exacerbates the risk of adverse drug events, drug-drug interactions, and PIMs use. Sometimes, prescribing cascades occur due to the use of multiple drugs. ${ }^{[8]}$

In conclusion, the present study results showed a higher prevalence of PIMs in the older adult patients with CVD and females with CVD has emerged as a potential PIM indicator. The study further reflects the need for physician's special attention on polypharmacy/high-level polypharmacy with comorbidities and extended hospital stay due to high risk for PIM. There is a need for compulsory training of physicians at all levels for 
the use of Beer criteria for better geriatric health care. Regulatory bodies need to set up geriatric health care desks in tertiary care hospitals to check such PIM incidences to reduce unnecessary economic burden due to infringement in following beer criteria. There is also a strong need to find out disease-wise PIM predictors in a broader range of the populations.

\section{References}

1. Jones JK. Assessing potential risk of drugs: the elusive target. ACP 1992.

2. Ramaswamy R, Maio V, Diamond JJ et al. Potentially inappropriate prescribing in elderly: assessing doctor knowledge, confidence and barriers. J Eval Clin Pract 2011; 17: 1153-9.

3. Thomas RE, Thomas BC. A systematic review of studies of the STOPP/START 2015 and American Geriatric Society Beers 2015 criteria in patients[?] 65 years. Curr Aging Sci2019; 12: 121-54.

4. Gorzoni ML, Rosa RF. Beers AGS 2019 criteria in very old hospitalized patients. AMB Rev Assoc Med Bras 2020; 66: 918-23.

5. Sharma R, Bansal P, Garg R et al. Prevalence of potentially inappropriate medication and its correlates in elderly hospitalized patients: A cross-sectional study based on Beers criteria. JFCM 2020; 27: 200.

6. Aguiar JP, Costa LH, da Costa FA, Leufkens HG, Martins AP. Identification of potentially inappropriate medications with risk of major adverse cardiac and cerebrovascular events among elderly patients in ambulatory setting and long-term care facilities. Clin Interv Aging 2019; 14: 535.

7. Duncan AK, Vittone J, Fleming KC, Smith HC, editors. Cardiovascular disease in elderly patients. Mayo Clin Proc 1996: Elsevier.

8. Veehof L, Stewart R, Meyboom-de Jong B, Haaijer-Ruskamp F. Adverse drug reactions and polypharmacy in the elderly in general practice. Eur J Clin Pharmacol 1999; 55: 533-6.

9. Mangoni AA, Jackson SH. Age-related changes in pharmacokinetics and pharmacodynamics: basic principles and practical applications. Br J Clin Pharmacol 2004; 57: 6-14.

10. Zhang X, Zhou S, Pan K et al. Potentially inappropriate medications in hospitalized older patients: a cross-sectional study using the Beers 2015 criteria versus the 2012 criteria. Clin Interv Aging 2017; 12:1697.

11. Sheikh-Taha M, Dimassi H. Potentially inappropriate home medications among older patients with cardiovascular disease admitted to a cardiology service in USA.BMC Cardiovasc Disor 2017; 17: 189.

12. Burkhardt H, Bojarsky G, Gretz N, Gladisch R. Creatinine clearance, Cockcroft-Gault formula and cystatin C: estimators of true glomerular filtration rate in the elderly? Gerontol 2002; 48: 140-6.

13. Corp I. IBM SPSS Statistics for Windows, Version 24.0. Armonk. IBM Corp NY; 2016.

14. Garcia-Ramos S, Garcia-Poza P, Ramos-Diaz F. Evaluation of inappropriate prescribing according to Beers criteria in cardiology and respiratory medicine departments. Revista de Calidad Asistencial: Organo de la Sociedad Espanola de Calidad Asistencial 2011; 27: 169-74.

15. Corleto VD, Festa S, Di Giulio E, Annibale B. Proton pump inhibitor therapy and potential long-term harm. Curr Opin Endocrinol Diabetes Obes 2014; 21: 3-8.

16. Umpierrez GE, Palacio A, Smiley D. Sliding scale insulin use: myth or insanity? Am J Med 2007; 120: 563-7.

17. Queale WS, Seidler AJ, Brancati FL. Glycemic control and sliding scale insulin use in medical inpatients with diabetes mellitus. Arch Intern Med 1997; 157: 545-52.

18. Franse LV, Pahor M, Di Bari M, Somes GW, Cushman WC, Applegate WB. Hypokalemia associated with diuretic use and cardiovascular events in the Systolic Hypertension in the Elderly Program. Hypertension 2000; 35: 1025-30. 
19. Curb JD, Pressel SL, Cutler JA, Savage PJ, Applegate WB, Black H, et al. Effect of diuretic-based antihypertensive treatment on cardiovascular disease risk in older diabetic patients with isolated systolic hypertension. JAMA 1996; 276: 1886-92.

20. 2019 American Geriatrics Society Beers Criteria(r) Update Expert Panel, Fick DM, Semla TP, Steinman M et al. American Geriatrics Society 2019 updated AGS Beers Criteria(r) for potentially inappropriate medication use in older adults.J Am Geriatr Soc 2019; 67: 674-94.

21. Markota M, Rummans TA, Bostwick JM, Lapid MI, editors. Benzodiazepine use in older adults: dangers, management, and alternative therapies. Mayo Clinic Proceedings ; 2016: Elsevier.

22. Hughes S, Szeki I, Nash MJ, Thachil J. Anticoagulation in chronic kidney disease patients - the practical aspects. Clin kidney J . 2014; 7:442-9.

23. Undela K, Bansal D, D'Cruz S, Sachdev A, Tiwari P. Prevalence and determinants of use of potentially inappropriate medications in elderly inpatients: a prospective study in a tertiary healthcare setting. Geriatr Gerontol Int 2014; 14: 251-8.

24. Huxley R, Barzi F, Woodward M. Excess risk of fatal coronary heart disease associated with diabetes in men and women: meta-analysis of 37 prospective cohort studies. Bmj 2006; 332: 73-8.

25. Oliveira SBVd, Barroso SCC, Bicalho MAC, Reis AMM. Profile of drugs used for self-medication by elderly attended at a referral center. Einstein (Sao Paulo) 2018; 16.

26. Turner BJ, Hollenbeak CS, Weiner M, Ten Have T, Tang SS. Effect of unrelated comorbid conditions on hypertension management. Ann Intern Med 2008; 148: 578-86.

27. Halanych JH, Safford MM, Keys WC et al. Burden of comorbid medical conditions and quality of diabetes care. Diabetes Care 2007; 30: 2999-3004.

28. Medicare Cf, Services M. Chronic conditions among Medicare beneficiaries, chartbook, 2012 edition. Baltimore, MD 2012; 11: 15-21.

29. Toh HJ, Lim ZY, Yap P, Tang T. Factors associated with prolonged length of stay in older patients.Singapore Med J 2017; 58: 134.

30. Wang X, Bonventre JV, Parrish AR. The aging kidney: increased susceptibility to nephrotoxicity. Int J Mol Sci 2014; 15: 15358-76.

Figure 1: Prevalence of chronic disease in older adult patients. IVD, Ischemic vascular disease; DCMP, Dilated Cardiomyopathy; CHF, Congestive Heart Failure; HTN, Hypertension; DM, Dilated Mellitus; CKD, Chronic Kidney disease; CLD, Chronic Liver disease; RD, Respiratory disease; PD, Psychiatric disorder;

Table 1: Socio-demographic and clinical characteristics of the older adult patients $(n=250)$

\begin{tabular}{lllll}
\hline Characteristics & Frequency & Percentage & Mean (SD) & Median (Minimum-1 \\
\hline Sex & Sex & Sex & & \\
Male & 150 & 60 & & \\
Female & 100 & 40 & $69(5)$ & $65(65-86)$ \\
Age (years) & & & \\
Educational Qualification & Educational Qualification & Educational Qualification & & \\
Illiterate & 168 & 67.2 & \\
$10^{\text {th }}$ passed & 46 & 18.4 & \\
$12^{\text {th }}$ passed & 22 & 8.8 & \\
Undergraduate & 14 & 5.6 & \\
Smoking & Smoking & Smoking &
\end{tabular}




\begin{tabular}{lllll}
\hline Characteristics & Frequency & Percentage & Mean (SD) & Median (Minimum- \\
\hline Chronic regular smoker & 40 & 16 & & \\
Ex-Smoker & 8 & 3.2 & & \\
Non-Smoker & 202 & 80.8 & & \\
Alcohol & Alcohol & Alcohol & & \\
Chronic regular alcoholic & 38 & 15.2 & & \\
Ex-alcoholic & 14 & 5.6 & & \\
Occasional alcoholic & 18 & 7.2 & $3(1)$ & $3(1-7)$ \\
Non alcoholic & 180 & 72 & $6(3)$ & $6(3-20)$ \\
No of diagnosis/comorbidities & & & $9(3)$ & $9(3-19)$ \\
Length of hospital stay (days) & & & $45(30)$ & $42(5-156)$ \\
No of medications & & & & \\
Creatinine clearance $(\mathrm{ml} / \mathrm{min})$ & & & & \\
\hline
\end{tabular}

Table 2: Prevalence of Potentially Inappropriate Medication Use in older adults patients with cardiovascular disease

\begin{tabular}{|c|c|c|c|c|}
\hline $\begin{array}{l}\text { Potentially } \\
\text { Inappropriate } \\
\text { Medication }\end{array}$ & No of patients & $\begin{array}{l}\text { Recommendation } \\
\text { by Beer guidelines }\end{array}$ & $\begin{array}{l}\text { Quality of } \\
\text { Evidence }\end{array}$ & $\begin{array}{l}\text { Strength of } \\
\text { Recommendation }\end{array}$ \\
\hline $\begin{array}{l}\text { Independent of } \\
\text { diagnosis }\end{array}$ & $\begin{array}{l}\text { Independent of } \\
\text { diagnosis }\end{array}$ & $\begin{array}{l}\text { Independent of } \\
\text { diagnosis }\end{array}$ & $\begin{array}{l}\text { Independent of } \\
\text { diagnosis }\end{array}$ & $\begin{array}{l}\text { Independent of } \\
\text { diagnosis }\end{array}$ \\
\hline Omeprazole & 18 & $\begin{array}{l}\text { Avoid Scheduled } \\
\text { use for }>8 \text { weeks } \\
\text { unless for high- } \\
\text { risk patients (e.g., } \\
\text { Oral } \\
\text { corticosteroids or } \\
\text { chronic NSAID } \\
\text { use), erosive } \\
\text { esophagitis, } \\
\text { Barrett's } \\
\text { esophagitis, } \\
\text { pathological } \\
\text { hypersecretory } \\
\text { condition, or } \\
\text { demonstrated } \\
\text { need for } \\
\text { maintenance } \\
\text { treatment }\end{array}$ & High & Strong \\
\hline Rabeprazole & 12 & & & \\
\hline Pantoprazole & 40 & & & \\
\hline Prazosin & 4 & $\begin{array}{l}\text { Avoid use as an } \\
\text { Antihypertensive }\end{array}$ & Moderate & Strong \\
\hline Glimepiride & 14 & Avoid & High & Strong \\
\hline
\end{tabular}




\begin{tabular}{|c|c|c|c|c|}
\hline $\begin{array}{l}\text { Potentially } \\
\text { Inappropriate } \\
\text { Medication }\end{array}$ & No of patients & $\begin{array}{l}\text { Recommendation } \\
\text { by Beer guidelines }\end{array}$ & $\begin{array}{l}\text { Quality of } \\
\text { Evidence }\end{array}$ & $\begin{array}{l}\text { Strength of } \\
\text { Recommendation }\end{array}$ \\
\hline $\begin{array}{l}\text { Human insulin, } \\
\text { according to } \\
\text { Random Blood } \\
\text { Sugar }\end{array}$ & 52 & $\begin{array}{l}\text { Avoid (insulin } \\
\text { regimens } \\
\text { containing only } \\
\text { short- or } \\
\text { rapid-acting } \\
\text { insulin dosed } \\
\text { according to } \\
\text { current blood } \\
\text { glucose levels } \\
\text { without } \\
\text { concurrent use of } \\
\text { basal or } \\
\text { long-acting } \\
\text { insulin) }\end{array}$ & Moderate & Strong \\
\hline Nitrofurantoin & 8 & $\begin{array}{l}\text { Avoid in } \\
\text { individuals with } \\
\text { creatinine } \\
\text { clearance } \\
<30 \mathrm{~mL} / \mathrm{min} \text { or } \\
\text { for long- term } \\
\text { suppression }\end{array}$ & Low & Strong \\
\hline Chlordiazepoxide & 3 & Avoid & Moderate & Strong \\
\hline Trihexyphenidyl & 2 & Avoid & Moderate & Strong \\
\hline Zolpidem & 3 & Avoid & Moderate & Strong \\
\hline Clonazepam & 22 & Avoid & Moderate & Strong \\
\hline Digoxin $0.25 \mathrm{mg}$ & 4 & $\begin{array}{l}\text { Avoid this rate } \\
\text { control agent as } \\
\text { first line therapy for } \\
\text { atrial fibrillation } \\
\text { Avoid as first- line } \\
\text { therapy for heart } \\
\text { failure. If used for } \\
\text { atrial fibrillation or } \\
\text { heart failure, avoid } \\
\text { dosages } \\
>0.125 \mathrm{mg} / \text { day. }\end{array}$ & $\begin{array}{l}\text { Atrial fibrillation: } \\
\text { low Heart failure: } \\
\text { low Dosage } \\
>0.125 \mathrm{mg} / \text { day: } \\
\text { moderate }\end{array}$ & $\begin{array}{l}\text { Atrial fibrillation: } \\
\text { strong Heart failure: } \\
\text { strong Dosage } \\
>0.125 \mathrm{mg} / \text { day: } \\
\text { strong }\end{array}$ \\
\hline Amiodarone & 6 & $\begin{array}{l}\text { Avoid as first- } \\
\text { line therapy for } \\
\text { atrial fibrillation } \\
\text { unless the patient } \\
\text { has heart failure } \\
\text { or substantial left } \\
\text { ventricular } \\
\text { hypertrophy }\end{array}$ & High & Strong \\
\hline Nortriptyline & 4 & Avoid & High & Strong \\
\hline Ketorolac & 4 & Avoid & Moderate & Strong \\
\hline Quetiapine & 8 & Avoid & Moderate & Strong \\
\hline Clonidine & 3 & Avoid & Low & Strong \\
\hline
\end{tabular}




\begin{tabular}{|c|c|c|c|c|}
\hline $\begin{array}{l}\text { Potentially } \\
\text { Inappropriate } \\
\text { Medication }\end{array}$ & No of patients & $\begin{array}{l}\text { Recommendation } \\
\text { by Beer guidelines }\end{array}$ & $\begin{array}{l}\text { Quality of } \\
\text { Evidence }\end{array}$ & $\begin{array}{l}\text { Strength of } \\
\text { Recommendation }\end{array}$ \\
\hline Ergot mesyloids & 2 & Avoid & High & Strong \\
\hline $\begin{array}{l}\text { Dependent of } \\
\text { diagnosis } \\
\text { Delirium }\end{array}$ & $\begin{array}{l}\text { Dependent of } \\
\text { diagnosis }\end{array}$ & $\begin{array}{l}\text { Dependent of } \\
\text { diagnosis }\end{array}$ & $\begin{array}{l}\text { Dependent of } \\
\text { diagnosis }\end{array}$ & $\begin{array}{l}\text { Dependent of } \\
\text { diagnosis }\end{array}$ \\
\hline Ranitidine & 3 & Avoid & Moderate & Strong \\
\hline Hydrocortisone & 3 & Avoid & Moderate & Strong \\
\hline $\begin{array}{l}\text { Drug-drug } \\
\text { interaction }\end{array}$ & $\begin{array}{l}\text { Drug-drug } \\
\text { interaction }\end{array}$ & $\begin{array}{l}\text { Drug-drug } \\
\text { interaction }\end{array}$ & $\begin{array}{l}\text { Drug-drug } \\
\text { interaction }\end{array}$ & $\begin{array}{l}\text { Drug-drug } \\
\text { interaction }\end{array}$ \\
\hline $\begin{array}{l}\text { Prazosin }+ \\
\text { Furosemide } \\
\text { Urinary } \\
\text { incontinence in } \\
\text { women }\end{array}$ & 2 & $\begin{array}{l}\text { Avoid in older } \\
\text { women }\end{array}$ & Moderate & Strong \\
\hline $\begin{array}{l}\text { Hydrocortisone }+ \\
\text { ketorolac } \\
\text { increased risk of } \\
\text { peptic ulcer or GI } \\
\text { bleeding }\end{array}$ & 2 & $\begin{array}{l}\text { Avoid; if not } \\
\text { possible, provide } \\
\text { gastrointestinal } \\
\text { protection }\end{array}$ & Moderate & Strong \\
\hline $\begin{array}{l}\text { Drugs that should } \\
\text { be used with } \\
\text { caution in older } \\
\text { adults }\end{array}$ & $\begin{array}{l}\text { Drugs that should } \\
\text { be used with } \\
\text { caution in older } \\
\text { adults }\end{array}$ & $\begin{array}{l}\text { Drugs that should } \\
\text { be used with } \\
\text { caution in older } \\
\text { adults }\end{array}$ & $\begin{array}{l}\text { Drugs that should } \\
\text { be used with } \\
\text { caution in older } \\
\text { adults }\end{array}$ & $\begin{array}{l}\text { Drugs that should } \\
\text { be used with } \\
\text { caution in older } \\
\text { adults }\end{array}$ \\
\hline $\begin{array}{l}\text { Aspirin for } \\
\text { primary } \\
\text { prevention of } \\
\text { cardiovascular } \\
\text { disease and } \\
\text { colorectal cancer }\end{array}$ & 12 & $\begin{array}{l}\text { Use with caution } \\
\text { in adults [?]70 } \\
\text { years }\end{array}$ & Moderate & Strong \\
\hline Furosemide & 6 & $\begin{array}{l}\text { Use with caution } \\
\text { as they may } \\
\text { exacerbate or } \\
\text { cause SIADH or } \\
\text { hyponatremia; } \\
\text { monitor sodium } \\
\text { level closely when } \\
\text { starting or } \\
\text { changing dosages } \\
\text { in older adults }\end{array}$ & Moderate & Strong \\
\hline Torsemide & 12 & & & \\
\hline Metolazone & 2 & & & \\
\hline $\begin{array}{l}\text { According to } \\
\text { creatinine } \\
\text { clearance of the } \\
\text { patient } \\
\text { Creatinine } \\
\text { clearance at } \\
\text { which action } \\
\text { required }(\mathrm{ml} / \mathrm{min})\end{array}$ & $\begin{array}{l}\text { According to } \\
\text { creatinine } \\
\text { clearance of the } \\
\text { patient }\end{array}$ & $\begin{array}{l}\text { According to } \\
\text { creatinine } \\
\text { clearance of the } \\
\text { patient }\end{array}$ & $\begin{array}{l}\text { According to } \\
\text { creatinine } \\
\text { clearance of the } \\
\text { patient }\end{array}$ & $\begin{array}{l}\text { According to } \\
\text { creatinine } \\
\text { clearance of the } \\
\text { patient }\end{array}$ \\
\hline
\end{tabular}




\begin{tabular}{|c|c|c|c|c|}
\hline $\begin{array}{l}\text { Potentially } \\
\text { Inappropriate } \\
\text { Medication }\end{array}$ & No of patients & $\begin{array}{l}\text { Recommendation } \\
\text { by Beer guidelines }\end{array}$ & $\begin{array}{l}\text { Quality of } \\
\text { Evidence }\end{array}$ & $\begin{array}{l}\text { Strength of } \\
\text { Recommendation }\end{array}$ \\
\hline $\begin{array}{l}\text { Enoxaparin } \\
<30 \mathrm{ml} / \mathrm{min}\end{array}$ & 32 & Reduced dose & Moderate & Strong \\
\hline $\begin{array}{l}\text { Spironolactone } \\
<30 \mathrm{ml} / \mathrm{min}\end{array}$ & 8 & Avoid & Moderate & Strong \\
\hline $\begin{array}{l}\text { Ranitidine } \\
<50 \mathrm{ml} / \mathrm{min}\end{array}$ & 8 & Reduced dose & Moderate & Strong \\
\hline Pregabalin $<60 \mathrm{ml} / \mathrm{min}$ & 6 & Reduced dose & Moderate & Strong \\
\hline $\begin{array}{l}\text { Gabapentin } \\
<60 \mathrm{ml} / \mathrm{min}\end{array}$ & 2 & Reduced dose & Moderate & Strong \\
\hline $\begin{array}{l}\text { Dabigatran } \\
<30 \mathrm{ml} / \mathrm{min}\end{array}$ & 4 & $\begin{array}{l}\text { Avoid; dose } \\
\text { adjustment } \\
\text { advised when } \\
\mathrm{CrCl}>30 \\
\mathrm{~mL} / \mathrm{min}\end{array}$ & Moderate & Strong \\
\hline $\begin{array}{l}\text { Trimethoprim- } \\
\text { sulfamethoxazole } \\
<30 \mathrm{ml} / \mathrm{min}\end{array}$ & 3 & $\begin{array}{l}\text { Reduced dose if } \\
\mathrm{CrCl} \\
15-29 \mathrm{ml} / \mathrm{min} \\
\text { Avoid if } \mathrm{CrCl} \\
<15 \mathrm{ml} / \mathrm{min}\end{array}$ & Moderate & Strong \\
\hline
\end{tabular}

NSAID, Nonsteroidal anti-inflammatory drug; SIADH, Syndrome of Inappropriate Antidiuretic Hormone Secretion

Table 3: Predictors of PIM in CVD with comorbidities in geriatric population

\begin{tabular}{|c|c|c|c|c|}
\hline Parameters & PIMs present & PIMs absent & $\begin{array}{l}\text { AGS Beers criteria } \\
2019 \text { OR }(95 \% \text { CI })\end{array}$ & ${ }^{*} \mathrm{P}$-value \\
\hline \multicolumn{5}{|l|}{ Gender } \\
\hline Male & 82 & 68 & 1 (reference) & \\
\hline Female & 74 & 26 & $2.36(1.36-4.09)$ & 0.002 \\
\hline \multicolumn{5}{|c|}{$\begin{array}{l}\text { No of } \\
\text { diagnosis/comorbidities }\end{array}$} \\
\hline 1 & 6 & 8 & 1 (reference) & \\
\hline 2 & 20 & 48 & $0.55(0.17-1.80)$ & 0.329 \\
\hline 3 & 58 & 18 & $4.29(1.31-14.0)$ & 0.016 \\
\hline$[?] 4$ & 72 & 20 & $4.8(1.49-15.44)$ & 0.009 \\
\hline \multicolumn{5}{|l|}{$\begin{array}{l}\text { Length of } \\
\text { Hospital stay } \\
\text { (days) }\end{array}$} \\
\hline $1-3$ & 12 & 24 & 1 (reference) & \\
\hline 4- 6 & 66 & 48 & $1.31(0.35-4.86)$ & 0.68 \\
\hline 7- 9 & 54 & 14 & $4.74(1.07-20.96)$ & 0.04 \\
\hline$>9$ & 24 & 8 & $1.09(0.19-6.11)$ & 0.91 \\
\hline \multicolumn{5}{|c|}{ No of medications } \\
\hline $1-4$ & 0 & 10 & 1 (reference) & \\
\hline $5-8$ & 38 & 42 & $0.08(0.01-0.40)$ & 0.002 \\
\hline [?] 9 & 118 & 42 & $0.09(0.01-0.50)$ & 0.006 \\
\hline
\end{tabular}




\begin{tabular}{|c|c|c|c|c|}
\hline Parameters & PIMs present & PIMs absent & $\begin{array}{l}\text { AGS Beers criteria } \\
2019 \text { OR }(95 \% \text { CI })\end{array}$ & ${ }^{*} \mathrm{P}$-value \\
\hline \multicolumn{5}{|l|}{$\begin{array}{l}\text { Creatinine } \\
\text { clearance } \\
\text { (ml/min) }\end{array}$} \\
\hline $1-30$ & 76 & 18 & 1 (reference) & \\
\hline $31-60$ & 52 & 32 & $0.38(0.19-0.75)$ & 0.006 \\
\hline $61-90$ & 24 & 36 & $0.15(0.07-0.32)$ & $<0.001$ \\
\hline $91-120$ & 4 & 4 & $0.23(0.05-1.03)$ & 0.056 \\
\hline$>120$ & 0 & 4 & & \\
\hline
\end{tabular}

${ }^{*} P<0.05$ indicates significant difference AGS, American Geriatric Society; PIM, potentially inappropriate medications; OR, odds ratio; CI, Confidence Interval

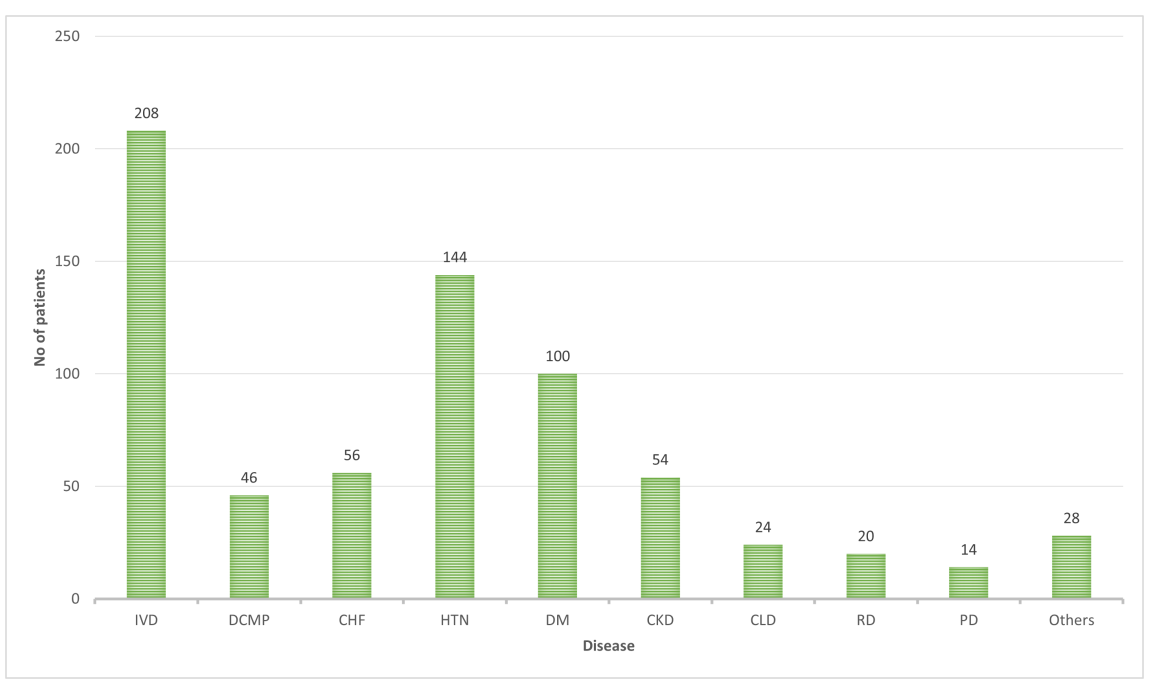

